DOI: $10.26693 / j m b s 05.05 .028$

UDC 616.311.2+616.314.17/.19)-002-092.9-003.93

Kordiyak Olena J.

\title{
Periodontal Destruction and Regeneration in Experimental Models: Combined Research Approaches
}

\author{
Lviv Danylo Halytskyi National Medical University, Ukraine
}

kordiyakolena68@gmail.com

Chronic periodontitis is a common dental disease, resulting in destruction of gingival tissue, periodontal ligament, cementum, alveolar bone and, consequently- teeth loss in the adult population. Experimental animal models have enabled the study of periodontal disease pathogenesis and are used to test new therapeutic approaches for treating the disease

The purpose of this review study was to draw the evidence from animal models, required for future assessment of destructional and regenerative processes in periodontal tissues.

Material and methods: a rat experimental periodontitis models of ligature, streptozotocin, and immune complexes induced periodontitis, periodontal defect, altered functional loading, stress exposures and surgically created chronic acid reflux esophagitis models.

Histomorphomorphological/-metrical, immunohisto (-cyto)chemical and histopathological analysis, micro-computed tomography, scanning and transmission electron microscopy, polarizing light and confocal microscopy, spectrophotometry, radiographic and biomechanical analysis, descriptive histology and computer-assisted image analysis.

Results and discussion. Scaling and root planing may not always be effective in preventing periodontal disease progression, and, moreover, with currently available therapies, full regeneration of lost periodontal tissues after periodontitis cannot be achieved. However, in $70.5 \%$ of the results of experimental studies reported, irrespective of the defect type and animal model used, beneficial outcome for periodontal regeneration after periodontal ligament stem cell implantation, including new bone, new cementum and new connective tissue formation, was recorded. Therefore, platelet-rich fibrin combined with rat periodontal ligament stem cells provides a useful instrument for periodontal tissue engineering.

Conclusion. There is sufficient evidence from preclinical animal studies suggesting that periodontal tissue engineering would provide a valuable tool for periodontal regeneration. Further elaboration of the developed in preclinical studies experimental techniques should justify progress to clinical studies and subsequent medical application.

Keywords: periodontal disease, experimental animal models, tissue engineering.
Connection of work with scientific programs, plans, themes. This study is the fragment of the complex research elaboration of the Department of Therapeutic Dentistry, Faculty of Postgraduate Education, Lviv Danylo Halytskyi National Medical University on the topic "Metabolic disorders and their influence on the development of combined stomatological and somatic pathology", № 0120 U002131 of the state registration.

Introduction. Chronic periodontitis is a common dental disease, resulting in destruction of gingival tissue, periodontal ligament, cementum, alveolar bone and, consequently, teeth loss in the adult population. Experimental animal models have enabled the study of periodontal disease pathogenesis and are used to test new therapeutic approaches for treating the disease [1].

Epidemiologic and clinical studies have indicated, that a risk factor for periodontal disease progression is diabetes mellitus as a metabolic disorder, resulting with many different complications, including soft tissue abnormalities in the oral cavity such as periodontitis and salivary and taste dysfunction [2, 3]. Zheng B. et al. (2017) noted that osteoporosis is associated with widespread periodontitis and impaired periodontal healing. However, there is a lack of information about the outcomes of regenerative approaches under the influence of osteoporosis [4]. In Zuza E. P. et al. (2018) opinion, obesity is related to greater alveolar bone loss and an accentuated local inflammatory response, which may be reflected in the clinical severity of periodontitis and dental loss [5]. Santos C. F. et al. (2015), Konermann A. et al. (2017) stated, that the initiation or progression of periodontitis might involve a local renin-angiotensin system, as well as the endocannabinoid system with its binding receptors $\mathrm{CB} 1$ and $\mathrm{CB} 2$, that impacts multiple pathophysiologies $[6,7]$.

Considering the evidence from animal models, implantation of periodontal ligament stem cells is emerging as a potential periodontal regenerative procedure [8]. The advantages and feasibility of periodontal tissue regeneration using platelet-rich fibrin combined with rat periodontal ligament stem cells, and the effects and mechanism of ipriflavone on the proliferation and osteoblastic differentiation of periodontal ligament cells in vitro and periodontal tissue remodeling following orthodontic tooth movement in vivo, were investigated by Duan X. et al. (2018) and 
Han Y. et al. (2018) [9, 10]. Increasing evidence indicates, that bone remodeling is under the control of factors related to neuronal regulation, but the underlying mechanisms remain largely unknown [11].

Nevertheless, according to Alves A. et al. (2019) reports, there is a lack of evidence data from animal models, which would be useful for studies of new periodontal treatments [12]. Scaling and root planing may not always be effective in preventing periodontal disease progression, and, moreover, with currently available therapies, full regeneration of lost periodontal tissues after periodontitis cannot be achieved [13, 14].

The purpose of this review study was to set out the evidence from animal models, required for future assessment of destructional and regenerative processes in periodontal tissues.

Material and methods. The rat models, used in the reviewed publications were: ligature-induced [5, 13, 15-19], streptozotocin-induced [2, 3, 20, 21] and immune complexes-induced [22] experimental periodontitis; 3-wall periodontal defect in Wistar rats [9, 14],osteoporotic rats periodontal fenestration defect model [4], apical periodontitis, induced in Wistar rats by pulp exposure to oral cavity [23], altered functional loading model with use of a hard and soft diet and the posterior bite-blocks in rats [24], as well as rats stress exposures in different modes [25], experimental rat model of surgically created chronic acid reflux esophagitis [26]. The combined bilayered compartmentalized system was used to promote the regeneration of alveolar bone in Wistar rats [14].

The results obtained were the subject of histomorphomorphological/-metrical [10, 13, 14, 17, $19,20,21-25,27-29,30]$, immunohisto (-cyto)chemical $[15,16,10,20,7,28,21,29,6,30,5,19]$ and histopathological [2, 4, 5, 9, 31, 22] analysis, micro-computed tomography $[9,15,16,18,19,21,24,28]$. The laboratory methods involved were real-time quantitative reverse- transcription polymerase chain reaction [11, 15, 16, 21] enzyme-linked immunosorbent assay [16, 17], scanning [3], and transmission electron microscopy [32], polarizing light microscopy [29], confocal microscopy and spectrophotometry [15], radiographic and biomechanical analysis [18], descriptive histology and computer-assisted image analysis [12].

PubMed, Embase, MEDLINE and Google Scholar were also searched for quantitative studies examining the outcome in experimental periodontal lesions in animals [8].

Results and discussion. The structural and compositional computerized assessment performed in the healthy periodontal soft tissue could provide reference values that will be required for future assessment on the effects of pathological, reparative and regenerative processes in rat periodontal soft tissues. The mild decalcification method allowed Alves
A. et al. (2019) in situ maintenance of the periodontal soft and hard tissue integrity, and histomorphometrical data showed that qualitatively, cellular and extracellular matrix morphologies were well preserved compared to non-decalcified periodontal soft tissue biopsies [12]. The effects of fluoxetine, a selective serotonin reuptake inhibitor, on the formation of the periodontal ligament collagen fibers in rats, and ipriflavone on new bone formation in the periodontal tissue in vivo, were assessed by Regueira L. S. et al. (2017) and Han Y. et al. [10, 29]. The effects of denervation on neuropeptide expression and bone remodeling-related factors in the rats, both of which govern the periodontal alveolar bone regeneration processes, were assessed by Yu X. et al. (2015) [11]. Bright R. et al. (2015) stated that there was sufficient evidence from preclinical animal studies to warrant moving to human studies to examine the efficacy, safety, feasibility (autologous vs. allogeneic transplantation) and delivery of periodontal ligament stem cells for periodontal regeneration [8]. In vitro and in vivo analyses were performed by Konermann $A$. et al. (2017) under physiological conditions and inflammatory states, further revealed expression changes of both tissue-selective receptors in mechanically loaded periodontal ligamant cells, thus indicating potential endocannabinoid system function as regulatory tool in controlling of periodontal pathophysiology [7]. Likewise, healthy and inflamed human gingiva expressed renin-angiotensin system components, some of which were shown to be functional, yet no differences in expression were found between healthy and diseased gingiva. Collectively, these data are consistent with the hypothesis, that a local renin-angiotensin system is not only present but is also functional in both human and rat periodontal tissue. Furthermore, blocking AT1R and renin can significantly prevent periodontal bone loss induced by experimental periodontitis in rats [6]. Kolesnikova L. R. et al. (2019) wrote that the intensity of morphological changes in the dental system tissues (periodontium and pulp) of rats depended on the mode of stress exposure. Acute stress was associated with a significant increase in the area of periodontal and pulp vessels, a decrease in the area of connective tissue of these components, and an increase in the thickness of the vascular endothelium. Chronic stress in these animals induced an increase in the thickness of the endothelial layer of the periodontal and pulp vessels, fibromatosis, and a sharp decrease in the level of odontoblasts [25]. Association between surgically created gastric acid reflux and oro- pharyngeal diseases has been elucidated by Shimazu R. et al. (2018). Furthermore, dental erosion progressed in gastroesophageal reflux disease in rats 20 weeks after surgery, and enamel erosion and dentin exposure were observed. During the same 
period, inflammatory cell infiltration was observed in the mucosa of the posterior part of the tongue. These findings suggest, that gastric acid reflux may be one of the exacerbating factors of dental erosion, periodontitis and glossitis [26].

Dag A. et al. (2016) were assured, that streptozotocin-induced diabetes may increase predisposition to periodontal disease by causing morphological changes in the periodontal tissues. It was observed, that in the diabetes group the epithelial thickness was greater, compared to the control group, and the congestion of the gingival capillaries, which showed that blood circulation was impaired in diabetes cases [2]. Characteristic morphological observations on the lingual mucosa of the streptozotocin treated rats were atrophic changes of lingual mucosa and the median rhomboid glossitis [3]. In rats with streptozotocininduced diabetes mellitus, local administration of tiludronic acid, antiresorptive and anti-inflammatory properties have not been evaluated in the periodontitis-diabetes mellitus association yet, and promoted a protective effect against tissue destruction [21]. The role of ascorbic acid in collagen synthesis in periodontal ligaments, using osteogenic disorder Shionogi has been clarified by Hasegawa T. et al. (2019). Thus, ascorbic acid insufficiency affected the immunolocalization of cathepsin H and MMP2. However, ligamentous fibroblasts appear to possess the potential to synthesize collagen fibers when supplied with ascorbic acid [32]. Estrogen deficiency in ovariectomized rats induced osteoporosis, changing the structure of buccal alveolar bone proper and the periodontal ligament, which is likely to increase the risk of periodontal disease [28]. According to Zheng B. et al. (2017), leptin overexpression in bone marrow stromal cells can stimulate periodontal regeneration in osteoporotic conditions and might be a promising strategy for periodontal regeneration in patients with osteoporosis [4].

The ligature-induced periodontitis model has several advantages as compared with other models, including rapid disease induction, predictable bone loss and the capacity to study periodontal tissue and alveolar bone regeneration [1]. Glucocorticoids can potentiate the destructive effects on alveolar bone tissue and alter the systemic bone loss, by promoting bone resorption and reducing osteoblast activity of rats with ligature-induced periodontitis [18]. The morphometric and histopathological changes the alveolar bone loss, the osteoblastic activity, the osteoclast number, inflammatory cell infiltration, associated with an experimental ligature-periodontitis model in rats in response to systemic administration of humic acid, were evaluated by Calisir M. et al. (2016). It can be suggested, that humic acid, when administered systemically as an $80 \mathrm{mg} / \mathrm{kg}$ dose, may prevent alveolar bone loss and reduce inflammation in the rat model
[17]. In rats with ligature-induced periodontitis, metfor$\mathrm{min}$ (at a concentration of $50 \mathrm{mg} / \mathrm{kg}$ ) decreases the inflammatory response, oxidative stress and bone loss [15]. Isoflavonoid puerarin at doses of 200 and 400 $\mathrm{mg} / \mathrm{kg}$ significantly reduced the alveolar bone loss, collagen destruction, inflammatory cell infiltration and osteoclast activity. Thus, puerarin can be considered a promising agent for adjunctive therapy of periodontitis [19]. In rats with ligature-induced periodontal disease, magnesium intake deficiency caused systemic effects, indicative of altered bone metabolism in the vertebrae and affected both immune and stromal cells, aggravating inflammatory bone resorption [16]. According to Zuza E. P. et al. (2018), obesity, induced by a high-fat diet influenced alveolar bone metabolism when associated with ligature-induced periodontitis in rats, and caused a more severe local inflammatory response and alveolar bone loss [5]. Although mice/rat are the most convenient and versatile animal models used in research, ligature-induced periodontitis has been more frequently used in large animals. In conclusion, this protocol enables the mechanistic study of the pathogenesis of periodontitis in vivo [1].

In $70.5 \%$ of the results, obtained by Bright $\mathrm{R}$. et al. (2015), irrespective of the defect type and animal model used, beneficial outcome for periodontal regeneration after periodontal ligament stem cell implantation, including new bone, new cementum and new connective tissue formation, was recorded. Owing to wide variability in surgical defect type, created in four species of animal (dog, rat, pig and sheep), cell source and cell scaffold in 43 studies, no metaanalysis was possible yet [8]. Babo P. S. et al. (2018) showed that the stabilization of platelet-origin proteins on the root surface increased the overall periodontal healing score for a period up to 6 weeks after implantation and restricted the formation of long epithelial junctions [14]. The recent findings of Noguchi S. et al. (2017) suggest that the destruction of periodontal tissue is increased in tissue containing long junctional epithelium compared with normal junctional epithelium, and that the immunized condition accelerates the destruction by forming immune complexes [22]. Nevertheless, the faster degradation of the cement component with incorporated hyaluronic acid microspheres compromised the stability of the combined compartmentalized system, which hampered the periodontal regeneration. Therefore, after optimization of the hard tissue analogue, the system should be further elaborated in (pre)clinical validation studies to assist predictable healing of functional periodontium [14]. Micro-computed tomography and histological analysis showed substantially more new bone formation in the platelet-rich fibrin + cells group at 24 days after surgery. Based on these results, Duan X. et al. (2018) suggested, that platelet-rich fibrin combined 
with rat periodontal ligament stem cells provides a valuable tool for periodontal tissue engineering [9]. The barrier function of long junctional epithelium is thought to be important after periodontal initial therapy and periodontal surgery. Although the difference between long junctional epithelium and normal junctional epithelium regarding their resistance to destruction of periodontal tissue has been investigated, the mechanism still remains unclear [22]. The effect of posterior bite-blocks, resin-based structures elevating the occlusion and creating intrusive force on the posterior teeth, on the periodontal ligament space and alveolar bone thickness when combined with altered masticatory forces was investigated by Denes B. J. et al. (2016) [24]. Young rats wearing posterior biteblocks have narrower periodontal ligament space and thinner alveolar bone compared to controls. When fed a soft diet, the alveolar bone is even thinner, but the periodontal ligament space showed no difference. The influence of different apical enlargement protocols on the radiographic and histological healing of apical periodontitis in rats was evaluated by Jara $\mathrm{C}$. M. et al. (2018). Under the experimental conditions of this study, a larger apical enlargement protocol favoured a more rapid radiographic and histological healing of apical periodontitis in rats after a 3-week follow-up compared with its respective control group [23]. The adjunctive effect of antimicrobial photodynamic therapy to scaling and root planing on ligatureinduced periodontal disease in rats was evaluated by deOliveira P. G. et al. (2016), analyzing histomorphometrical, immunohistochemical, and immunoenzymatic parameters. It was concluded, that the adjunctive use of photodynamic therapy in combination with scaling and root planing showed the best therapeutic results in the treatment of periodontal disease in rats after 3 and 15 days [13]. The positive effects of systemic and local ozone application on alveolar bone loss in a Wistar rat periodontitis model and Singlet phototherapy in the treatment of periodontal diseases in an experimental study were determined by Saglam E. et al. (2019) and Bazikyan E. A. et al. (2018) [27, 30]. Radiation therapy and protective melatonin administration produced noticeable biochemical and histochemical effects on periodontal tissues in rats with experimental periodontitis in Kose O. et al. (2017) study. It was found, that radiotherapy increased oxidative stress, the periodontal attachment level and alveolar bone loss, and protective melatonin administration significantly reduced the oxidative parameters and prevented periodontal damage in irradiated rats. The need of further research regarding the use of systemic melatonin administration before radiation therapy was pointed out [31]. The effects of the GaAlAs diode laser on the periodontal tissues were assessed and its action on the alveolar bone remodeling process during orthodontic tooth movement in normoglycemic and diabetic rats was investigated by Gomes M. F. et al. (2017). The photobiomodulation strongly stimulated the periodontal tissue response alveolar bone remodeling, establishing mainly the balance between the bone formation and resorption and favored the continuous reorganization of the soft periodontal tissues, leading to the maintenance and integrity of the periodontal microstructure under orthodontic force, especially in uncontrolled diabetic rats [20].

Conclusion. There is sufficient evidence from preclinical animal studies suggesting that periodontal tissue engineering would provide a valuable tool for periodontal regeneration. Further elaboration of the developed in preclinical studies experimental techniques should justify progress to clinical studies and subsequent medical application.

Prospective for the further research is to determine selection criteria for the priority implementation of respective experimental data into the periodontal treatment protocols.

\section{References}

1. Marchesan J, Girnary MS, Jing L, Miao MZ, Zhang S, Sun L, et al. An experimental murine model to study periodontitis. Nat Protoc. 2018; 13(10): 2247-2267. doi: 10.1038/s41596-018-0035-4

2. Dağ A, Fırat ET, Uysal E, Ketani MA, Şeker U. Morphological Changes Caused by Streptozotocin-Induced Diabetes in the Healthy Gingiva of Rats. Exp Clin Endocrinol Diabetes. 2016; 124(3): 167-72. doi: 10.1055/s0035-1559781

3. Ortug G, Ignak S, Ortug A. Characteristics of lingual papillae in diabetic rats. Morphologie. 2018; 102(339): 250254. doi: 10.1016/j.morpho.2018.08.003

4. Zheng B, Jiang J, Chen Y, Lin M, Du Z, Xiao Y, et al. Leptin Overexpression in Bone Marrow Stromal Cells Promotes Periodontal Regeneration in a Rat Model of Osteoporosis. J Periodontol. 2017; 88(8): 808-818. doi: 10.1902/jop.2017.170042

5. Zuza EP, Garcia VG, Theodoro LH, Ervolino E, Favero LFV, Longo M, et al. Influence of obesity on experimental periodontitis in rats: histopathological, histometric and immunohistochemical study. Clin Oral Investig. 2018; 22(3): 1197-1208. doi: 10.1007/s00784-017-2207-y

6. Santos CF, Morandini AC, Dionísio TJ, Faria FA, Lima MC, Figueiredo CM, et al. Functional Local ReninAngiotensin System in Human and Rat Periodontal Tissue. PLoS One. 2015; 10(8): e0134601. doi: 10.1371/ journal.pone. 0134601 
7. Konermann A, Jäger A, Held SAE, Brossart P, Schmöle A. In vivo and In vitro Identification of Endocannabinoid Signaling in Periodontal Tissues and Their Potential Role in Local Pathophysiology. Cell Mol Neurobiol. 2017; 37(8): 1511-1520. doi: 10.1007/s10571-017-0482-4

8. Bright R, Hynes K, Gronthos S, Bartold PM. Periodontal ligament-derived cells for periodontal regeneration in animal models: a systematic review. J Periodontal Res. 2015; 50(2): 160-72. doi: 10.1111/jre.12205

9. Duan X, Lin Z, Lin X, Wang Z, Wu Y, Ji M, et al. Study of platelet-rich fibrin combined with rat periodontal ligament stem cells in periodontal tissue regeneration. J Cell Mol Med. 2018; 22(2): 1047-1055. doi: 10.1111/jcmm.13461

10. Han Y, Wang X, Ma D, Wu X, Yang P, Zhang J. Ipriflavone promotes proliferation and osteogenic differentiation of periodontal ligament cells by activating GPR30/PI3K/AKT signaling pathway. Drug Des Devel Ther. 2018; 12: 137-148. doi: 10.2147/DDDT.S148457

11. Yu X, Li L, Zhang J, Zhang T, Xiao C, Li S. Expression of neuropeptides and bone remodeling-related factors during periodontal tissue regeneration in denervated rats. J Mol Histol. 2015; 46(2): 195-203. doi: 10.1007/ s10735-015-9611-x

12. Alves A, Attik N, Wirth C, Bayon Y, Piat A, Grosgogeat B, Gritsch K. Cellular and collagen reference values of gingival and periodontal ligament tissues in rats: a pilot study. Histochem Cell Biol. 2019; 152(2): 145-153. doi: 10.1007/s00418-019-01789-1

13. deOliveira PG, Silveira E Souza AM, Novaes AB Jr, Taba M Jr, Messora MR, et al. Adjunctive effect of antimicrobial photodynamic therapy in induced periodontal disease. Animal study with histomorphometrical, immunohistochemical, and cytokine evaluation. Lasers Med Sci. 2016; 31(7): 1275-83. doi: 10.1007/s10103-016-1960-5

14. Babo PS, Cai X, Plachokova AS, Reis RL, Jansen J, Gomes ME, Walboomers XF. Evaluation of a platelet lysate bilayered system for periodontal regeneration in a rat intrabony three-wall periodontal defect. J Tissue Eng Regen Med. 2018; 12(2): e1277-e1288. doi: 10.1002/term.2535

15. Araújo AA, Pereira ASBF, Medeiros CACX, Brito GAC, Leitão RFC, Araújo LS, et al. Effects of metformin on inflammation, oxidative stress, and bone loss in a rat model of periodontitis. PLoS One. 2017; 12(8): e0183506. doi: 10.1371/journal.pone.0183506

16. Belluci MM, de Molon RS, Rossa C Jr, Tetradis S, Giro G, Cerri PS, et al. Severe magnesium deficiency compromises systemic bone mineral density and aggravates inflammatory bone resorption. J Nutr Biochem. 2020; 77: 108301. doi: 10.1016/j.jnutbio.2019.108301

17. Çalışır M, Akpınar A, Poyraz Ö, Göze F, Çınar Z. The histopathological and morphometric investigation of the effects of systemically administered humic acid on alveolar bone loss in ligature-induced periodontitis in rats. $J$ Periodontal Res. 2016; 51(4): 499-507. doi: 10.1111/jre.12329

18. Sousa LH, Moura EV, Queiroz AL, Val D, Chaves H, Lisboa M, et al. Effects of glucocorticoid-induced osteoporosis on bone tissue of rats with experimental periodontitis. Arch Oral Biol. 2017; 77: 55-61. doi: 10.1016/j.archoralbio.2017.01.014

19. Yang X, Zhang H, Wang J, Zhang Z, Li C. Puerarin decreases bone loss and collagen destruction in rats with ligature-induced periodontitis. J Periodontal Res. 2015; 50(6): 748-57. doi: 10.1111/jre.12261

20. Gomes MF, da Graças VGM, Giannasi LC, Hiraoka CM, de Fátima SMG, de Sousa AGV, et al. Effects of the GaAIAs diode laser $(780 \mathrm{~nm})$ on the periodontal tissues during orthodontic tooth movement in diabetes rats: histomorphological and immunohistochemical analysis. Lasers Med Sci. 2017; 32(7): 1479-1487. doi: 10.1007/ s10103-017-2268-9

21. Nunes NLT, Messora MR, Oliveira LF, Lisboa M, Garcia MCB, Rêgo RO, et al. Effects of local administration of tiludronic acid on experimental periodontitis in diabetic rats. J Periodontol. 2018 Jan; 89(1): 105-116. doi: 10.1902/jop.2017.170228

22. Noguchi S, Ukai T, Kuramoto A, Yoshinaga Y, Nakamura H, Takamori Y, et al. The histopathological comparison on the destruction of the periodontal tissue between normal junctional epithelium and long junctional epithelium. J Periodontal Res. 2017; 52(1): 74-82. doi: 10.1111/jre.12370

23. Jara CM, Hartmann RC, Böttcher DE, Souza TS, Gomes MS, Figueiredo JAP. Influence of apical enlargement on the repair of apical periodontitis in rats. Int Endod J. 2018; 51(11): 1261-1270. doi: 10.1111/iej.12949

24. Denes BJ, Bresin A, Kiliaridis S. The influence of altered functional loading and posterior bite-blocks on the periodontal ligament space and alveolar bone thickness in rats. Acta Odontol Scand. 2016; 74(7): 518-524.

25. Kolesnikova LR, Darenskaya MA, Kolesnikova LI, Grebenkina LA, Korytov LI, Batoroev YK, et al. Changes in the Periodontium and Pulp in ISIAH Rats Caused by Stress Exposures in Different Modes. Bull Exp Biol Med. 2019; 166(6): 722-725. doi: 10.1007/s10517-019-04426-y

26. Shimazu R, Yamamoto M, Minesaki A, Kuratomi Y. Dental and oropharyngeal lesions in rats with chronic acid reflux esophagitis. Auris Nasus Larynx. 2018; 45(3): 522-526. doi: 10.1016/j.anl.2017.08.011

27. Bazikyan EA, Syrnikova NV, Chunikhin AA, Zayratyants OV. [Morphological evaluation of singlet phototherapy in the treatment of periodontal diseases in an experimental study]. Stomatologiia. 2018; 97(1): 22-26. [Russian]. doi: 10.17116/stomat201897122-26 
28. Liu Z, Liu L, Kang C, Xie Q, Zhang B, Li Y. Effects of estrogen deficiency on microstructural changes in rat alveolar bone proper and periodontal ligament. Mol Med Rep. 2015; 12(3): 3508-3514. doi: 10.3892/mmr.2015.3891

29. Regueira LS, Marcelos PG, Santiago-Jaegger IM, Perez DE, Evêncio J Neto, Baratella-Evêncio L. Fluoxetine effects on periodontogenesis: histomorphometrical and immunohistochemical analyses in rats. J Appl Oral Sci. 2017; 25(2): 159-167. doi: 10.1590/1678-77572015-0564

30. Saglam E, Alinca SB, Celik TZ, Hacisalihoglu UP, Dogan MA. Evaluation of the effect of topical and systemic ozone application in periodontitis: an experimental study in rats. J Appl Oral Sci. 2019; 28: e20190140. doi: 10.1590/1678-7757-2019-0140

31. Köse O, Arabaci T, Kizildag A, Erdemci B, Özkal ED, Gedikli S, et al. Melatonin prevents radiation-induced oxidative stress and periodontal tissue breakdown in irradiated rats with experimental periodontitis. J Periodontal Res. 2017; 52(3): 438-446. doi: 10.1111/jre.12409

32. Hasegawa T, Miyamoto-Takasaki Y, Abe M, Qiu Z, Yamamoto T, Yoshida T, et al. Histochemical examination on principal collagen fibers in periodontal ligaments of ascorbic acid-deficient ODS-od/od rats. Microscopy (Oxf). 2019; 68(5): 349-358. doi: 10.1093/jmicro/dfz021

\section{УДК 616.311.2+616.314.17/.19)-002-092.9-003.93 \\ РУЙНУВАННЯ ТА РЕГЕНЕРАЦІЯ ПАРОДОНТА В ЕКСПЕРИМЕНТАЛЬНИХ МОДЕЛЯХ: ПОЄДНАНІ ПІДХОДИ НАУКОВИХ ДОСЛІДЖЕНЬ Кордіяк Олена Й.}

Резюме. Хронічний пародонтит є поширеним стоматологічним захворюванням, що призводить до руйнування тканин ясен, періодонтальних зв'язок, цементу, альвеолярної кістки і, як наслідок, втрати зубів у дорослого населення. Експериментальні моделі на тваринах дозволили вивчити патогенез пародонтиту та використовуються для тестування нових терапевтичних підходів до лікування захворювання

Mema цього оглядового дослідження - викласти доказові дані, отримані на експериментальних моделях у тварин, які необхідні для подальшого вивчення деструктивних та регенеративних процесів у тканинах пародонту.

Матеріали та методи: Моделі експериментального пародонтиту у щурів з використанням лігатури, стрептозотоцину та імунних комплексів, дефектів пародонта, зміненого фрункціонального навантаження, впливом стресу та модель, пов'язана з хірургічно-створеним хронічним рефлюкс-езофагітом.

Гістоморфоморфологічний / -метричний, імуногісто (-цито) хімічний та гістопатологічний аналіз, мікро-комп'ютерна томографія, скануюча та просвічувальна електронна мікроскопія, поляризуюче світлова та конфокальна мікроскопія, спектрофотометричний аналіз, рентгенологічний та біомеханічний аналіз, комп'ютерний аналіз зображень.

Очищення та згладжування коренів не завжди можуть бути ефективними для запобігання прогресуванню пародонтозу, і, крім того, завдяки наявним на сьогодні методам лікування, неможливо досягти повної регенерації втрачених тканин пародонту після пародонтозу. Однак у 70,5\% результатів експериментальних досліджень, незалежно від типу дефекту та використовуваної моделі тварини, було зафріксовано сприятливий результат для регенерації пародонту після імплантації стовбурових клітин періодонтальної зв'язки, включаючи нову кістку, новий цемент та утворення сполучної тканини. Тому багатий на тромбоцити фібрин у поєднанні зі стовбуровими клітинами періодонтальної зв'язки щурів $€$ цінним інструментом для інженерії тканин пародонту.

Існує достатньо доказів, отриманих з доклінічних досліджень на тваринах про те, що тканинна інженерія надає корисні засоби для регенерації пародонту. Подальше удосконалення розроблених на доклінічних дослідженнях експериментальних методик зможе дати можливість для переходу до клінічних випробувань та подальшого медичного застосування.

Ключові слова: хвороба пародонту, експериментальні моделі у тварин, тканинна інженерія.

\section{УДК 616.311.2+616.314.17/.19)-002-092.9-003.93 \\ РАЗРУШЕНИЕ И РЕГЕНЕРАЦИЯ ПАРОДОНТА В ЭКСПЕРИМЕНТАЛЬНОЙ МОДЕЛИ: СОВМЕЩЕННЫЕ ПОДХОДЫ НАУЧНЫХ ИССЛЕДОВАНИЙ Кордияк Олена Й.}

Резюме. Хронический пародонтит является распространенным стоматологическим заболеванием, приводящим к разрушению тканей десны, периодонтальных связок, цемента, альвеолярной кости и, как следствие, потери зубов у взрослого населения. Экспериментальные модели на животных позволили изучить патогенез пародонтита и используются для тестирования новых терапевтических подходов к лечению заболевания 
Цель этого обзорного исследования - выложить доказательные данные, полученные на экспериментальных моделях у животных, которые необходимы для дальнейшего изучения деструктивных и регенеративных процессов в тканях пародонта.

Материалы и методы: Модели экспериментального пародонтита у крыс с использованием лигатуры, стрептозотоцина и иммунных комплексов, дефектов пародонта, измененного функциональной нагрузки, влияние стресса и модель, связанная с хирургически-созданным хроническим рефлюкс-эзофагитом.

Гистоморфоморфологический / -метрический, имуногисто (-цито) химический и гистопатологический анализ, микро-компьютерная томография, сканирующая и просвечивающая электронная микроскопия, поляризующе световая и конфокальная микроскопия, спектрофотометрический анализ, рентгенологический и биомеханический анализ, компьютерный анализ изображений.

Очищение и сглаживания корней не всегда могут быть эффективными для предотвращения прогрессирования пародонтоза, и, кроме того, благодаря имеющимся на сегодня методам лечения, невозможно достичь полной регенерации утраченных тканей пародонта после пародонтоза. Однако в 70,5\% результатов экспериментальных исследований, независимо от типа дефекта и используемой модели животных, был зафиксирован благоприятный результат для регенерации пародонта после имплантации стволовых клеток периодонтальной связки, включая новую кость, новый цемент и образования соединительной ткани. Поэтому богатый тромбоцитами фрибрин в сочетании со стволовыми клетками периодонтальной связки крыс является ценным инструментом для инженерии тканей пародонта.

Существует достаточно доказательств, полученных в процессе доклинических исследований на животных о том, что тканевая инженерия предоставляет полезные средства для регенерации пародонта. Дальнейшее совершенствование разработанных на доклинических исследованиях экспериментальных методик может дать возможность перехода к клиническим испытаниям и дальнейшего медицинского применения.

Ключевые слова: заболевания пародонта, экспериментальные модели у животных, тканевая инженерия.

The authors of this study confirm that the research and publication of the results were not associated with any conflicts regarding commercial or financial relations, relations with organizations and/or individuals who may have been related to the study, and interrelations of coauthors of the article. 